Human Resource Management 
Also by Frank Burchill

LABOUR RELATIONS 


\title{
Human Resource Management
}

\section{The NHS: A Case Study}

\author{
Frank Burchill \\ and \\ Alice Casey
}




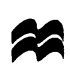

CC Frank Burchill and Alice Casey 1996

All rights reserved. No reproduction, copy or transmission of this publication may be made without written permission.

No paragraph of this publication may be reproduced, copied or transmitted save with written permission or in accordance with the provisions of the Copyright, Designs and Patents Act 1988, or under the terms of any licence permitting limited copying issued by the Copyright Licensing Agency, 90 Tottenham Court Road, London W1P 9HE.

Any person who does any authorised act in relation to this publication may be liable to criminal prosecution and civil claims for damages.

First published 1996 by

MACMILLAN PRESS LTD

Houndmills, Basingstoke, Hampshire RG21 6XS

and London

Companies and representatives

throughout the world

ISBN 978-0-333-60913-2 ISBN 978-1-349-24806-3 (eBook)

DOI 10.1007/978-1-349-24806-3

A catalogue record for this book is available from the British Library.

$\begin{array}{llllllllll}10 & 9 & 8 & 7 & 6 & 5 & 4 & 3 & 2 & 1\end{array}$

$\begin{array}{llllllllll}05 & 04 & 03 & 02 & 01 & 00 & 99 & 98 & 97 & 96\end{array}$ 


\section{Contents}

List of Abbreviations vii

Introduction $\quad \mathrm{xi}$

1 Human Resource Planning 1

2 The HRM Debate 21

3 Industrial Relations in NHS 43

4 Industrial Relations at the Place of Work 65

5 Health and Safety at Work 89

6 Equal Opportunities $\quad 105$

7 Human Resource Development 119

8 Recruitment and Selection 133

9 Redundancy 147

10 Case Studies 157

11 Pay and Flexibility in the NHS 171

Appendix: The National Health Service 187

References $\quad 197$

Index 201 
To Bernard and Bridie Molly and Peter 


\section{Abbreviations}

AAC

A\&C

A\&E

ACAS

ACB

AEEU

AHA

APEX

ASC

ASTMS

AUEW

BAOT

BDA

BDA

BHA

BMA

$B M J$

BOS

BQA

CATS

CBI

CDNA

CENTEC

CEO

Advisory Appointments Committee

administrative and clerical

accident and emergency

Advisory, Conciliation and Arbitration Service

Association of Clinical Biochemists

Amalgamated Engineering and Electrical Union

Area Health Authority

Association of Professional, Executive, Clerical

and Computer Staff

Ancillary Staff Committee

Association of Scientific, Technical and

Managerial Staffs

Amalgamated Union of Engineering Workers

British Association of Occupational Therapists

British Dental Association

British Dietetic Association

British Hospitals Association

British Medical Association

British Medical Journal

British Orthoptic Society

British Quality Association

credit accumulated transfer schemes

Confederation of British Industry

COHSE Confederation of Health Service Employees

COSHH Control of Substances Hazardous to Health

Regulations 1988

CPSM Council for the Professions Supplementary

to Medicine

CRE Commission for Racial Equality

CSP Chartered Society of Physiotherapists

DDRB Doctors' and Dentists' Review Body 


\begin{tabular}{ll} 
DGH & district general hospital \\
DGM & district general manager \\
DHA & District Health Authority \\
DHSS & Department of Health and Social Security \\
DMT & district management team \\
DMU & directly managed unit \\
DNA & District Nursing Association \\
DOCAS & deduction of contributions at source \\
DOH & Department of Health \\
DPO & district personnel officer \\
EC & European Community \\
EETPU & Electrical, Electronic, Telecommunications \\
& and Plumbing Union \\
EL & executive letter \\
EOC & Equal Opportunities Commission \\
EOP & equal opportunities policy \\
EPA & Equal Pay Act 1970 \\
EP(C)A & Employment Protection (Consolidation) Act 1978 \\
EU & European Union \\
EVA & Equal Value Amendment 1983 \\
FCE & finished consultant episode \\
FTE & full time equivalent \\
GDC & General Dental Council \\
GMB & GMB Union \\
GMBATU & General Municipal, Boilermakers and Allied \\
& Trades Union \\
GMC & General Medical Council \\
GNP & gross national product \\
GP & general practitioner \\
GPF & general practitioner fundholder \\
GWC & General Whitley Council \\
HCA & health care assistant \\
HCHS & hospital and community health services \\
HCSA & Hospital Consultants' and Specialists' Association \\
HPA & Hospital Physicists Association \\
HR & human resource \\
HRM & human resource management \\
HSC & Health and Safety Commission \\
HSCC & hospital staff consultative committee \\
HSE & Health and Safety Executive \\
\hline &
\end{tabular}


HSWA Health and Safety etc at Work Act 1974

HVA Health Visitors' Association

IHSM Institute of Health Service Management

ILO International Labour Organisation

IPD Institute of Personnel and Development

IR industrial relations

JCC joint consultative committee

JIT just-in-time

JNC joint negotiating committee

JSC joint staff committee

JSCC joint staff consultative committee

JSSC joint shop stewards committee

LEU local employment unit

MHSWR Management of Health and Safety at Work

Regulations 1992

MLSO medical laboratory scientific officer

MSF Manufacturing, Science and Finance

NAHAT National Association of Health Authorities and

Trusts

NAHA National Association of Health Authorities

NALGO National and Local Government Officers Association

NHS National Health Service

NHSE National Health Service Executive

NHSTD National Health Service Training

Directorate/Division

NUPE National Union of Public Employees

NVQ National Vocational Qualification

OME Office of Manpower Economics

PAM professions allied to medicine

PBR payment-by-results

PCR professional contribution rating

PES public expenditure survey

PI

performance indicator

PM personnel management

POWAR place of work accredited representatives

PRB pay review body

PRP performance-related pay

PT'A' Professional and Technical Council 'A'

PT'B' Professional and Technical Council 'B'

QAT quality action team 


$\begin{array}{ll}\text { RAWP } & \text { resource allocation working party } \\ \text { RCM } & \text { Royal College of Midwives } \\ \text { RCN } & \text { Royal College of Nursing } \\ \text { RHA } & \text { Regional Health Authority } \\ \text { RIDDOR } & \text { Reporting of Injuries, Diseases and Dangerous } \\ & \text { Occurrences Regulations 1985 } \\ \text { RM } & \text { registered midwife } \\ \text { RN } & \text { registered nurse } \\ \text { RO } & \text { regional office } \\ \text { SEA } & \text { Single European Act } \\ \text { SEN } & \text { state enrolled nurse } \\ \text { SGT } & \text { self-governing trust } \\ \text { SHO } & \text { senior house officer } \\ \text { SoC } & \text { Society of Chiropodists } \\ \text { SoR } & \text { Society of Radiographers } \\ \text { SRN } & \text { state registered nurse } \\ \text { TGWU } & \text { Transport and General Workers Union } \\ \text { TQC } & \text { total quality control } \\ \text { TQI } & \text { total quality improvement } \\ \text { TQM } & \text { total quality management } \\ \text { TUC } & \text { Trade Union Congress } \\ \text { TULR(C)A } & \text { Trade Union and Labour Relations } \\ & \text { (Consolidation) Act 1992 } \\ \text { TURERA } & \text { Trade Union Reform and Employment Rights } \\ & \text { Act 1993 } \\ \text { UCATT } & \text { Union of Construction, Allied Trades and } \\ & \text { Technicians } \\ \text { UGM } & \text { unit general manager } \\ \text { UKCC } & \text { United Kingdom Central Council } \\ \text { ULC } & \text { unit labour cost } \\ \text { UNISON } & \text { public sector trade union formed by a merger } \\ & \text { of COHSE, NALGO and NUPE } \\ \text { USDAW } & \text { Union of Shop, Distributive and Allied Workers } \\ \text { VDU } & \text { visual display unit } \\ \text { WHO } & \text { World Health Organisation } \\ \text { WTE } & \text { whole time equivalent } \\ & \end{array}$




\section{Introduction}

The objective of this book is to provide an introduction to those topics generally associated with the term 'human resource management' (HRM). It is intended that this will be a broad introduction, but linked together by reference to a coherent set of examples of practice applied within the National Health Service. These examples reflect practice at the time of writing. They are not presented in any prescriptive sense, but simply to help illustrate the topics considered and, perhaps, to generate a better understanding of the issues raised.

As a term, HRM is not treated as problematic. It is simply treated as one which is generally replacing 'personnel management' as a title for the area of study under consideration. Current texts with HRM in the title usually end up discussing practice in the three major areas traditionally associated with personnel management texts: resourcing; development; employee relations. Torrington and Hall (1995), which keeps personnel management as its main title, clearly follows this pattern. Storey and Sisson (1993), which has the title 'Managing Human Resources and Industrial Relations', focuses exactly on the same three areas.

This is not to say that all such texts have identical concerns or analyses. The separating out of HRM and industrial relations in the text referred to above is of some significance. According to Storey and Sisson (1993:2), 'personnel management could be traditionally understood as concerned with policies and practices directed towards the individual employee, whereas, industrial relations could be suitably regarded as concerned with collective labour issues' (italics in original). Torrington and Hall (1991: especially 501-35) have not been inhibited by such a distinction they include a consideration of collective labour issues. The above comment is also at odds with Clegg (1979:1).

What is industrial relations? The answer which is assumed in this book is that it is the study of the rules governing employment, together with the ways in which rules are made and changed, interpreted and administered. Implicit in this defini- 


\section{xii Introduction}

tion is the notion that industrial relations is as concerned with those policies which are directed at the individual as it is with those directed at the collective. It could, however, be argued that the section on collective issues in Torrington and Hall derives from the subject matter of industrial relations and that the distinctive feature of personnel management is its concern with resourcing and development.

There is another distinction. Texts on personnel management are generally prescriptive. They usually attempt to describe 'good' or 'effective' practice. Texts on industrial relations tend to be analytical, have a historical perspective and place emphasis on the importance of power and shifts in its balance. There is no reason why such an analysis should not be applied to the whole field of personnel management. This would lead us to examine what is going on within the three areas of activity and perhaps explore why.

Attempts to identify the substance of HRM usually consist of producing a list of characteristics supposedly describing personnel management/industrial relations (PM/IR) and a contrasting list for HRM (see Storey, 1992:35). In such models we find, for example, that PM/IR tends to be pluralist, HRM, unitarist; the business plan is marginal to PM/IR but central to HRM; 'facilitation' is prized by HRM as a managerial skill rather than 'negotiation', which is favoured by PM/IR, and so on. Similarly, there are 'hard' and 'soft' versions of HRM.

It is possible to argue that in the traditional areas of concern for students of personnel management there have been widespread changes of practice, with common elements, but unevenly distributed. These changes can be primarily located in the 1980s and the 1990s. The interesting questions are: What are these changes? Why have they taken place? Why are there variations? Why do they occur unevenly? Whether a particular combination of changes or practices constitutes HRM as opposed to $\mathrm{PM} / \mathrm{IR}$ is singularly uninteresting. Hence the lack of concern relating to the title used in this text.

Storey and Sisson (1993:50) say: 'Superficially, given the reduction in overt industrial conflict and the apparent increase in attention to human resource matters by general and line managers as well as personnel specialists, the industrial relations and HR problem might seem to be close to a solution.' As far as the 
authors of this text are concerned there is no 'problem' and therefore no 'solution'. There are areas of activity and change which are worthy of study. These areas of activity for the purpose of this text are the human resourcing of organisations in industry, the development of staff in these organisations, and what is variously called 'employee', 'labour' or 'industrial' relations. Participants in these activities will perceive both problems and solutions. The origins of such perceptions will need to be examined and placed in the context of wider economic and political considerations.

The NHS has been variously reorganised since its creation in 1948. In 1990, the NHS and Community Care Act was a major step in the radical reforms of the NHS which had progressed throughout the 1980s. This introduced the internal market and brought into full play a whole range of commercial practices generally associated with the private sector. The rhetoric of financial accountability was used to put pressure on NHS costs and in particular labour costs. Compulsory competitive tendering had already preceded this development. These changes put tremendous pressure on the general employment and HRM practices of employing units, such as hospitals and community units, as they became trusts and are judged by financial criteria.

Paralleling these developments were general pressures from the National Health Service Executive (NHSE) to mimic the HRM practices of the private sector. NHS trusts, to varying degrees, have absorbed the practice of issuing mission statements, talking about total quality and world excellence, introducing performance-related pay and attempting the range of flexibilities in terms of employment practices. The dismantling of Whitley and the pay review bodies have drawn trusts into local pay determination. So far, trusts have generally held back from derecognition of unions. Whether this is to facilitate the shorterrun changes remains to be seen.

This book has been written in the midst of wholesale change in the NHS. It examines the range of HRM policies of a trust. The objective is to provide a case study which allows background and theoretical analysis of such policies to be given practical content. As such, the text should be of use to general students of the subject. It also chronicles the experiences of a trust in this important period of NHS development. 
The text is structured in such a way that it allows for the statement of basic HRM principles which are then related to practice in a trust. This is therefore a general text on HRM with practical examples which follow in an integrated fashion. It begins with human resource planning, a topic which allows for an overview of the subject of HRM and the organisation under consideration. This is followed by some examination of the debate relating to the meaning of HRM which is used to provide a device for introducing a discussion of current management practices and their origins. Most of what follows the Chapter 2 section on current management practices is relatively straightforward. For teaching purposes, a chapter has been included which contains case studies. This is very much rooted in changes taking place at the time of writing and in particular the development of bargaining. It is the authors' view that the issues arising, and the effects on practice, will continue for a long time to be of importance, not only in the NHS, but in other industries also.

Frank BURChILL

Alice Casey

\section{Acknowledgements}

The authors and publishers are grateful to the following for permission to reproduce copyright material: OPCS for Tables 1.1 and A.1 and Figures 1.1, A.3 and A.4; KPMG Management Consulting and Central Manchester Healthcare Trust for Table 11.1; and NAHAT for Figures A.1, A.2 and A.5. 